Article

\title{
Evaluation of Satellite-Derived Rainfall Estimates for an Extreme Rainfall Event over Uttarakhand, Western Himalayas
}

\author{
Bikash Ranjan Parida ${ }^{1, *}$, Sailesh N. Behera ${ }^{2}$, Oinam Bakimchandra ${ }^{3}$, Arvind Chandra Pandey ${ }^{1}$ \\ and Nilendu Singh ${ }^{4}$ \\ 1 Centre for Land Resource Management (CLRM), School of Natural Resource \& Management, \\ Central University of Jharkhand, Ranchi 835205, Jharkhand, India; arvindchandrap@yahoo.com \\ 2 Department of Civil Engineering, Center for Environmental Science \& Engineering (CESE), \\ Shiv Nadar University, Greater Noida 201314, U.P., India; saileshnb@gmail.com \\ 3 Department of Civil Engineering, National Institute of Technology, Imphal 795001, Manipur, India; \\ bakim143@gmail.com \\ 4 Centre for Glaciology, Wadia Institute of Himalayan Geology, Dehradun 248001, Uttarakhand, India; \\ nilendu_singh@yahoo.com \\ * Correspondence: bikashrp@gmail.com; Tel.: +91-799-225-7184 \\ Academic Editor: Jai Vaze \\ Received: 8 February 2017; Accepted: 23 March 2017; Published: 30 March 2017
}

\begin{abstract}
The extreme rainfall event during June 2013 in the Western Himalayas caused widespread flash floods, which triggered landslides, a lake-outburst, and debris flow. For the hydrological study of such an unexpected extreme event, it is essential to have reliable and accurate rainfall predictions based on satellite observations. The mountainous state of Uttarakhand is covered by complex topography, and this state has few, unevenly distributed, rain gauge networks. This unique study was conducted to evaluate three satellite based rainfall products (i.e., TMPA-3B42, Global Satellite Mapping of Precipitation (GSMaP), and NOAA CPC Morphing Technique (CMORPH)) against the observed rain gauge-based India Meteorological Department (IMD) gridded dataset for this rainfall episode. The results from this comprehensive study confirmed that the magnitude of precipitation and peak rainfall intensity were underestimated in TMPA-3B42 and CMORPH against gauge-based IMD data, while GSMaP showed dual trends with under- and over-predictions. From the results of the statistical approach on the determination of error statistic metrics (MAE (mean absolute error), NRMSE (normalized root mean square error), PBIAS (percent bias), and NSE (Nash-Sutcliffe efficiency)) of respective satellite products, it was revealed that TMPA-3B42 predictions were more relevant and accurate compared to predictions from the other two satellite products for this major event. The TMPA-3B42-based rainfall was negatively biased by $18 \%$. Despite these caveats, this study concludes that TMPA-3B42 rainfall was useful for monitoring extreme rainfall event in the region, where rain-gauges are sparse.
\end{abstract}

Keywords: extreme rainfall event; Kedarnath disaster; satellite rainfall products; IMD; TRMM; TMPA; GSMaP; mass curve and hyetograph; Mandakini valley

\section{Introduction}

The atmospheric phenomenon caused through the collision of a Western disturbance with the monsoonal cloud system led to a major hydro-meteorological disaster in the region covering Uttarakhand (an Indian state) and its adjacent areas during 16-17 June 2013 [1]. In this week (13-19 June), Rudraprayag district of Uttarakhand state has received $366.3 \mathrm{~mm}$ of intense unprecedented rainfall, which was $580 \%$ more than the normal rainfall $(54 \mathrm{~mm})$. The recurrence of this multi-day cloud 
caused massive flash floods due to the extreme rainfall-type event, a so-called "cloudburst" that subsequently triggered landslides, debris flow, and mudflow in the region. Cloudburst is a localized extreme weather event that occurs at a faster rate under which the rainfall intensity may increase to $100 \mathrm{~mm} / \mathrm{h}$ [2]. This occurs over orographically-dominant regions like the Himalayan region during monsoon season and often leads to flash floods. While the June 2013 Uttarakhand event resembles a cloudburst, the Kedarnath disaster was critically attributed to multi-day heavy downpouring, snow fall, and the subsequent outburst of the moraine-dammed Chorabari Lake [3]. This episode was considered as a major hydro-meteorological disaster in the history of this state due to its widespread affected area and immense destruction of life and properties including 10,000 fatalities and devastation of natural ecosystems, and of man-made buildings and properties [4]. Specifically, this natural disaster in Kedarnath had caused a drop in 93\% pilgrims, affecting tourism revenue of 120-200 billion Indian rupees $(\Upsilon)$ and the livelihood of about 0.2 million families residing in the region $[5,6]$.

During the last decade (2003-2013), cloudburst-based flash floods recurring during monsoon season (June to September) are among the major disasters at high altitude areas of the Himalayas. Over these years, out of 24 flash floods, half of these events were witnessed during 2010 at several districts of Uttarakhand (India). Among these hydrological disasters the 2013 flash flood was the strongest that affected many districts, including Bageshwar, Chamoli, Pithoragarh, Rudraprayag, and Uttarkashi. In the perspectives of increase in recurrence of flash floods followed by severe consequences from glacial lake outburst floods (GLOFs) in the Western Himalayas [5], it is necessary to conduct a study on systematic evaluation of satellite-based rainfall estimates (SBRE) products. To the best of our knowledge, no such study has attempted, so far, to evaluate the predictability of satellite rainfall products for an extreme rainfall event over the Western Himalayas, albeit many studies have analyzed time series datasets of satellite estimates for hydrological applications [6-8]. As SBRE rainfall products with high spatial-temporal resolution data are crucial drivers for hydrological applications and model development activities, they need to be evaluated and validated against measurements from rain-gauge stations or existing benchmarked data. Accurate and precise predictions of precipitation have significant implications in hydrological modeling, weather forecasting, and climate change studies. Therefore, it is imperative to know satellite rainfall products in terms of their spatial distribution, magnitude, duration, and peak intensity of the precipitation for an extreme rainfall event.

Rain gauges and meteorological radars are the conventional tools used to monitor intense rainfall events, but over this complex geographical heterogeneity region, homogenous networks of observation stations are not available. The IMD continuously expanded gauge networks in the Himalayas; however, the maintenance cost over this mountainous terrain becomes expensive to afford on a routine basis [9]. Hence, rainfall retrieved from satellite sensors are the only accessible tool for monitoring such an unprecedented extreme episode. The satellite data can provide hourly rainfall data covering large spatial extents and act as a valuable data source for hydrological applications. Since 1997, microwave satellite data from the Tropical Rainfall Measuring Mission (TRMM) provides a real-time measurement of rainfall using the precipitation radar (PR) sensor that operates at $13.8 \mathrm{GHz}$. It provides a detailed vertical distribution of radar reflectivity and information on intensity and distribution of the rain [10,11]. After the TRMM satellite, numerous high-resolution multi-satellite rainfall products have been developed, namely, TRMM Multisatellite Precipitation Analysis (TMPA), GSMaP, GPCP-1DD, CPC-RFE2, CMORPH, PERSIANN, TAMSAT, and EPSAT [12]. These products are usually derived from the passive microwave (PMW) radiometers (low-Earth orbiting satellites), coupled with geostationary infrared (IR) data. 
Numerous applications were undertaken comprehensively using the aforementioned products. Some of these applications include extreme rainfall events, annual water budgeting, flood modelling, and drought monitoring [13-17]. While foolproof precipitation estimates are preferred, studies have pointed out various rainfall estimate errors owing to the instrument, algorithm, sampling method, and georeferencing [18-20]. Calibration of satellite-based rainfall estimation methods were reported by various studies, $[21,22]$ suggesting that SBRE products were more reliable in tropical regions due to typical association of precipitation with deep convection [23]. Bookhagen and Burbank [6] have analyzed 1741 gauge stations from the Himalayan-Tibetan areas and revealed that the SBRE rainfall products correlated well with the rain-gauge stations even at high rainfall amounts across elevation regions, ranging from 500 to $5000 \mathrm{~m}$, which represented a usable rainfall distribution over this complex topography [22]. Notably, SBRE rainfall products for an extreme rainfall episode were not evaluated in inhomogeneous rugged topography of Western Himalayan regions.

To address the literature gaps in previous studies, the main objectives of this comprehensive study were to evaluate the capacity of three SBRE rainfall products against the IMD gridded gauge-based dataset during an extreme rainfall event, and to determine their appropriateness as an additional option to conventional tools (i.e., rain gauge) for use in hydrological predictions and applications. In particular, we evaluated three SBRE products, namely, TMPA-3B42, Global Satellite Mapping of Precipitation (GSMaP), and NOAA CPC Morphing Technique (CMORPH). This study also aimed to map the key elements (i.e., villages, population, and the historical heritage) vulnerable to risks caused by the Kerdarnath disaster during June 2013.

\section{Study Area}

The study area is the Uttarakhand state (situated in the northern part of India) which is part of the Western Himalayas regions and situated in the upper Ganga river basin (Figure 1). The entire state has 40 rain gauge stations that often restrict the scopes of the hydrological studies over this complex topography. The state is well-known to pilgrims because of Chardham spiritual uniqueness (Kedarnath, Badrinath, Gangotri, and Yamunetri) and thousands of pilgrims and tourists usually congregate during summer months. Prominent physiographic features comprise Siwaliks (sub-Himalayan region) and the Himalayan region with undulated topography that consists of snow clad mountain peaks, scatter crests, deep valleys, and glaciers. The Chorabari glacier is a medium size glacier (3900-6420 m) situated near Kedarnath covering an approximate area of $6.6 \mathrm{~km}^{2}$ with an ice volume of 744.1 million $\mathrm{m}^{3}$ [24]. It has an average surface slope of $20^{\circ}$ and it is covered by thick debris along the glacier. The glacier has retreated $344 \mathrm{~m}$ during the period of 1962-2012 with an average rate of $6.8 \mathrm{~m}$ per annum [25]. The long-term average retreat rate has increased significantly from 6 to $9 \mathrm{~m}$ in the recent decade (2003-2012), which suggests a significant global climate change. The catchment area of Chorabari Lake (elevation $3960 \mathrm{~m}$ ) is a moraine-dammed lake that represents an area of about $2 \mathrm{~km}^{2}$ with the maximum water depth of 15-20 m [24,25]. This natural reservoir is called as Gandhi-Sarovar Lake, which is usually fed by glacial and snow-melted water. This lake suddenly collapsed during the June 2013 ensuing flash floods in the Saraswati River and Mandakini River and the rivers changed their respective courses, with further sedimentation settling up to $6 \mathrm{~m}$ [26]. The Kedarnath town $\left(30^{\circ} 44^{\prime} 6.7^{\prime \prime} \mathrm{N}\right.$ and $\left.79^{\circ} 04^{\prime} 1^{\prime \prime} \mathrm{E}\right)$ is located $2 \mathrm{~km}$ downstream from Chorabari Lake and this region witnessed major devastation during June 2013. 


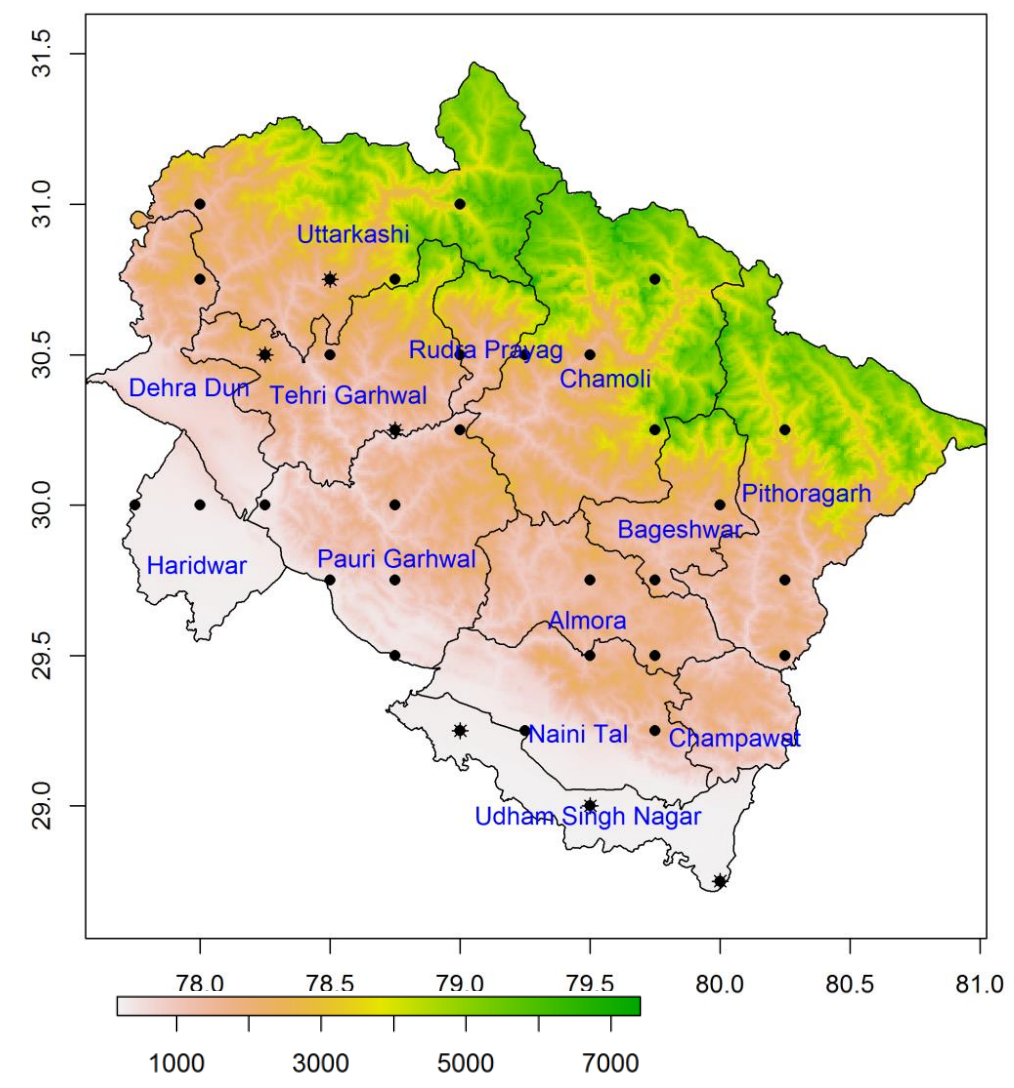

Figure 1. Location map of Uttarakhand state, located in the northern part of India comprising 13 districts. The point symbols indicate locations of IMD rain-gauge stations, whereas star indicates two IMD rain gauge stations. Surface elevation $(\mathrm{m})$ shows the terrain condition (elevation data source: GTOP30, USGS).

\section{Materials and Methods}

\subsection{TMPA-3B42 Rainfall Data}

The TMPA consists of three products, namely, three-hourly (3B42), daily (3B42 derived), and monthly (3B43) products. The TMPA is designed to combine precipitation estimates both from satellite systems and precipitation gauge analyses. The TMPA depends on input from various sets of sensors such as the Microwave Imager (TMI) on TRMM, Special Sensor Microwave Imager (SSM/I) on Defense Meteorological Satellite Program (DMSP) satellites, Advanced Microwave Scanning Radiometer-Earth Observing System (AMSR-E) on Aqua, the Advanced Microwave Sounding Unit-B (AMSU-B) on the National Oceanic and Atmospheric Administration (NOAA) satellite series, and the Microwave Humidity Sounder (MHS) [11,27,28]. The algorithm of TMPA consists of four stages, described as follows: (i) microwave precipitation estimates are calibrated and combined; (ii) infrared precipitation estimates are created using the calibrated microwave precipitation; (iii) microwave and IR estimates are combined; and (iv) calibration against rain gauge data. The TMPA is a merged multi-satellite precipitation product with a native resolution of $0.25^{\circ}$ latitude and longitude [11,27]. In this study, we employed TMPA daily precipitation product called 3B42 (version 7: v7) to analyze the duration and magnitude of observed rainfall product and to compare with other satellite rainfall products. The latest version 7 data were obtained from the utilities of NASA GES/DISC (http://mirador.gsfc.nasa.gov). These products are described concisely in Table 1, as given below. 
Table 1. Features of satellite rainfall products used in this study.

\begin{tabular}{c|c|c|c|c}
\hline \multirow{2}{*}{ Features } & Conventional Data & \multicolumn{3}{|c}{ SBRE Products } \\
\cline { 2 - 5 } & IMD-Gauge & TMPA-3B42 (v7) & CMORPH & GSMaP \\
\hline $\begin{array}{c}\text { Spatial \& Temporal } \\
\text { resolution }\end{array}$ & $\begin{array}{c}0.25^{\circ} \text { grid } \\
\text { Daily }\end{array}$ & $\begin{array}{c}0.25^{\circ} \text { grid } \\
\text { Daily }\end{array}$ & $\begin{array}{c}0.25^{\circ} \text { grid } \\
\text { 3-hourly }\end{array}$ & $\begin{array}{c}0.1^{\circ} \text { grid } \\
\text { Daily }\end{array}$ \\
\hline Sensors involved & - & IR, TMI, SSM/I, & IR, TMI, SSM/I, \\
& AMSR-E, AMSU-B & $\begin{array}{c}\text { IR, TMI, SSM/I, } \\
\text { AMSR-E, AMSU-B }\end{array}$ \\
\hline Interpolation method & IDW [29] & - & - & - \\
\hline Coverage & India & Global & Global & Global \\
\hline Gauge calibrated & Yes & Yes & No & Yes \\
\hline Agency & IMD & NASA \& JAXA & NOAA CPC & JAXA \\
\hline Reference & {$[30]$} & {$[10]$} & {$[31]$} & {$[32]$} \\
\hline
\end{tabular}

\subsection{NOAA CPC Morphing Technique (CMORPH) Rainfall Data}

The CMORPH precipitation data has been derived from four types of passive microwave (PMW) instruments, namely, TMI, AMSU-B, SSM/I, and the AMSR-E [31]. The IR data determines cloud motion, which is applied to the PMW-derived rainfall features. Further, the shape and intensity of the rainfall patterns are modified by morphing [33]. The CMORPH data were available at a native spatial resolution of $0.25^{\circ}$ latitude and longitude grid (see Table 1 detailed information). In this study, we employed a temporal resolution of three-hourly data. They were summed to daily time-scale to analyze rainfall magnitude for comparison with other satellite rainfall products during this extreme rainfall event during June 2013. The variable used for this study was 'CMORPH precipitation estimate'. The data were obtained from the Research Data Archive (Climate Prediction Centre, NOAA) managed by the Computational and Information Systems Laboratory (http://rda.ucar.edu).

\subsection{JAXA (GSMaP) Rainfall Data}

The JAXA Global Rainfall Watch provides the Global Satellite Mapping of Precipitation (GSMaP) rainfall products. Here, we employed GSMaP of daily averaged gauge-calibrated rainfall product (the GSMaP_Gauge) which was derived from various sensors at $0.1^{\circ}$ latitude and longitude grid [34]. The GSMaP_Gauge was an adjusted product derived from the Microwave-IR Merged Algorithm (GSMaP_MVK), being estimated with global gauge analysis (CPC—Unified Gauge) provided by NOAA The GSMaP_MVK was an integrated product from passive microwave radiometer and infrared radiometer data [32]. The microwave sensors used were TMI, AMSU-B, SSM/I, and the AMSR-E (for details, see Table 1). The daily dataset obtained from the JAXA Global Rainfall Watch (http://sharaku.eorc.jaxa.jp/GSMaP) were used to compare with other satellite rainfall products. For simplicity, henceforth, the GSMaP_Gauge product is referred to as GSMaP.

\subsection{India Meteorological Department (IMD) Rainfall Data}

The historical IMD rainfall data (1901, onwards) were archived at the National Data Center (NDC), Pune. The daily precipitation fields over the Indian mainland were derived from dense network of 7000 rain-gauge stations, and based on this dataset, the National Climate Centre (NCC) builds gridded rainfall data interpolated into regular high spatial resolution of $0.25^{\circ}$ latitude and longitude grid [30,35]. The IMD employed the inverse distance weighted interpolation (IDW) method proposed by Shepard [29] for interpolating daily rainfall from rain gauge points to grid points. This is a standard and the latest dataset for India developed by IMD and detailed description and quality control were mentioned in Pai et al. [30]. Many studies were performed using the previous version of IMD data at $0.5^{\circ}$ latitude and longitude grid [36]. These studies comprise intra-seasonal to inter-annual variability of rainfall, climate variability, modelled rainfall validations, hydrological applications, drought monitoring, etc. [8,37-39]. The IMD dataset was used as an input for the APHRODITE dataset over Asia, developed by Japan [40]. The IMD data is a standard product for India and, thus, in this study, we considered IMD data as a benchmark data for evaluating other multi-satellite rainfall products for this extreme rainfall event. 


\subsection{Wadia Institute of Himalayan Geology (WIHG) Daily Discharge and Rainfall Data}

To analyze the runoff pattern during this extreme event [24,41], we utilized both the daily discharge rate and the daily rainfall data collected by WIHG. These data were based on the point observations and, especially, the daily discharge rates were collected at Sitapur (Gaurikund) in Mandakini valley, located downstream of Kedarnath. Rain-gauges from WIHG were located at Kopardhar (Ghuttu) near Kedarnarth.

\subsection{Other Ancillary Data}

The affected villages and population data were obtained from the Rudraprayag-Uttarakhand district administration [42], Census India [43], Pragya Report [44], and AID-JHU Report [45]. The Geographic Information System (GIS) analyses were performed to map affected villages and populations, along with the surface elevations. The digital elevation model (DEM) data were obtained from the GTOPO30 with a spatial resolution of $1 \mathrm{~km} \mathrm{[46],} \mathrm{available} \mathrm{from} \mathrm{the} \mathrm{U.S.} \mathrm{Geological} \mathrm{Survey}$ (USGS). The number of pilgrims and tourists visiting Kedarnath were obtained from the Uttarakhand Tourism Department [47].

\subsection{Methods}

The benchmark data used in this study was IMD gauge-based dataset with a $0.25^{\circ}$ latitude and longitude grid. The binary format of IMD data was converted to raster using open source grads. Both TMPA-3B42 and CMORPH data were available at $0.25^{\circ}$ latitude and longitude resolution and the binary format of these products were converted to raster format using the "raster" package in $\mathrm{R}$ [48]. The GSMaP data were obtained at $0.1^{\circ}$ latitude and longitude resolution. The dataset, namely, IMD, TMPA, and CMORPH, with $0.25^{\circ}$ latitude and longitude resolution, were resampled to $0.1^{\circ}$ resolution based on the nearest neighborhood method. The resampled data were further subjected to a smoothening function that uses a matrix of weights (the moving window of $3 \times 3$ matrix) for the neighborhood of the focal cells. The aforementioned steps were performed using the $\mathrm{R}$ package "raster" [48]. All maps were generated using the R package "sp" [49] and throughout, geographic latitude and longitude projection (WGS-84 datum) was used for all maps. Most of the products had daily temporal resolution, except the CMORPH dataset. The latter was available with three-hourly variations and, for consistency, they were summed to a daily time-scale. We generated 82 random points (circular pattern) over four districts of Uttarakhand (as referred to Section 4.2) to extract satellite-based rainfall values. The values of rainfall from these 82 points were extracted based on the bilinear method (averaged over four grid points) and then extracted precipitation data were compared with IMD-gauge dataset. These data points were also used to perform an inter-comparison between SBRE products and gridded IMD gauge data using various quantitative statistical indicators, namely, MAE (mean absolute error), NRMSE (normalized root mean square error), PBIAS (percent bias), and NSE (Nash-Sutcliffe efficiency), as described in Equations (1)-(4) below:

$$
\begin{gathered}
M A E=\frac{1}{N} \sum_{t=1}^{N} S A T_{i}-G_{i} \\
N R M S E=\frac{\sqrt{\frac{1}{N} \sum_{t=1}^{N}\left(S A T_{i}-G_{i}\right)^{2}}}{\bar{G}} 100 \\
\text { PBIAS }=\frac{\sum_{t=1}^{N}\left(S A T_{i}-G_{i}\right)}{\sum_{t=1}^{N} G_{i}} 100 \\
N S E=1-\frac{\sum_{t=1}^{N}\left(S A T_{i}-G_{i}\right)^{2}}{\sum_{t=1}^{N}\left(S A T_{i}-\bar{G}_{i}\right)^{2}}
\end{gathered}
$$


where, $G$ = gauge (IMD), $\bar{G}=$ average of gauge, SAT = satellite data (i.e., TMPA-3B42, GSMaP, $\mathrm{CMORPH}$ ), and $N=$ number of data pairs. The MAE is in mm, NRMSE and PBIAS are in percent, while NSE is dimensionless. The NRMSE gives the standard deviation of the satellite estimates error, and a smaller value indicates higher accuracy in satellite estimation. The PBIAS measures the average tendency of the satellite estimates to be larger or smaller than their gauge measurements. Positive values of PBIAS indicate overestimation by satellite data, whereas negative values of PBIAS indicate underestimation. The NSE is a normalized statistic that defines the skill of the satellite estimates compared to the gauge-based data [50,51]. Typically, the NSE values range from $-\infty$ to 1 , and close to 1 means more accurate satellite estimates. Negative values indicate that the observed mean is better than the satellite estimates.

The mass curve and hyetograph were plotted to identify the number of storms and timing of storms based on the TMPA-3B42. The rainfall estimates from TMPA were further compared with rain-gauge station data from IMD and WIHG. Later, we mapped the key elements vulnerable to risk, such as villages and populations, along with surface elevation, using GIS. By doing so, we attempted to highlight affected areas in and around Kedarnath due to such extreme rainfall events.

\section{Results}

\subsection{Spatial Pattern of Precipitation Retrieved from SBRE Products and Conventional IMD-Based Gauge Stations}

We have presented the utilization of SBRE rainfall products for evaluation of rainfall pattern for an extreme rainfall event like Kedarnath disaster over the Uttarakhand during June 2013. Figure 2 depicts the spatial distribution of accumulated precipitation during 15 to 18 June over Uttarakhand, wherein we compared three SBRE rainfall products, such as GSMaP, TMPA, and CMORPH, with the IMD (observations-interpolated) dataset. These maps clearly indicate that the spatial pattern of precipitation especially from the IMD was widespread, and most of the regions were observed with precipitation $>200 \mathrm{~mm}$. In addition, some districts (i.e., Dehradun, Uttarkashi, Tehri Garhwal, Naini Tal) have witnessed precipitation of $350 \mathrm{~mm}$. Kedarnath, located near Chorabari Lake, was demarcated in these maps, where IMD recorded precipitation of $232 \mathrm{~mm}$. As compared to IMD, the satellite estimates were 225, 212, and $151 \mathrm{~mm}$ for GSMaP, TMPA, and CMORPH, respectively. So, for a single grid-point (i.e., Kedarnath), the satellite estimates showed negative precipitation biases with PBIAS as $-3 \%$, $-8.6 \%$, and $-35 \%$ for GSMaP, TMPA, and CMORPH, respectively. Based on a visual comparison, TMPA showed that precipitation was well distributed over the state as compared to IMD. However, the magnitude of precipitation differs with respect to IMD, whereas GSMaP showed both under and overestimation of precipitation irrespective of surface elevation. However, CMORPH precipitation was underestimated considerably across many grid-points, as the product was not calibrated against the rain gauge data.

Visual comparison of satellite estimates indicated that precipitation was underestimated in the CMORPH product over all districts of Uttarakhand state, except a few districts, namely, Uttarkashi, Dehradun, and Tehri Garhwal. By contrast, rain gauge-calibrated satellite estimates of GSMaP and TMPA were closer to the reference IMD gauge data, although few regions exhibited dissimilarity. Notably, precipitation from GSMaP was overestimated over northern districts (Uttarkashi, Dehradun, Haridwar, and Tehri Garhwal) of Uttarakhand as compared to IMD, while southern and eastern districts of Uttarakhand state (Almora, Naini Tal, Champawat, Chamoli, Pithoragarh, Bageshwar) were underestimated. By comparing all three products with IMD data, we did not find any distinct differences of underestimation and overestimation of precipitation with respect to surface elevation. In general, the spatial extent of precipitation of TMPA-3B42 was well distributed across all of the districts of Uttarakhand as compared to the GSMaP and CMORPH, albeit its magnitude was lower than IMD gauge-based precipitation. We described the quantitative evaluation of satellite-based estimates with gauge-based rainfall using the standard statistical metrics in the subsequent section. 


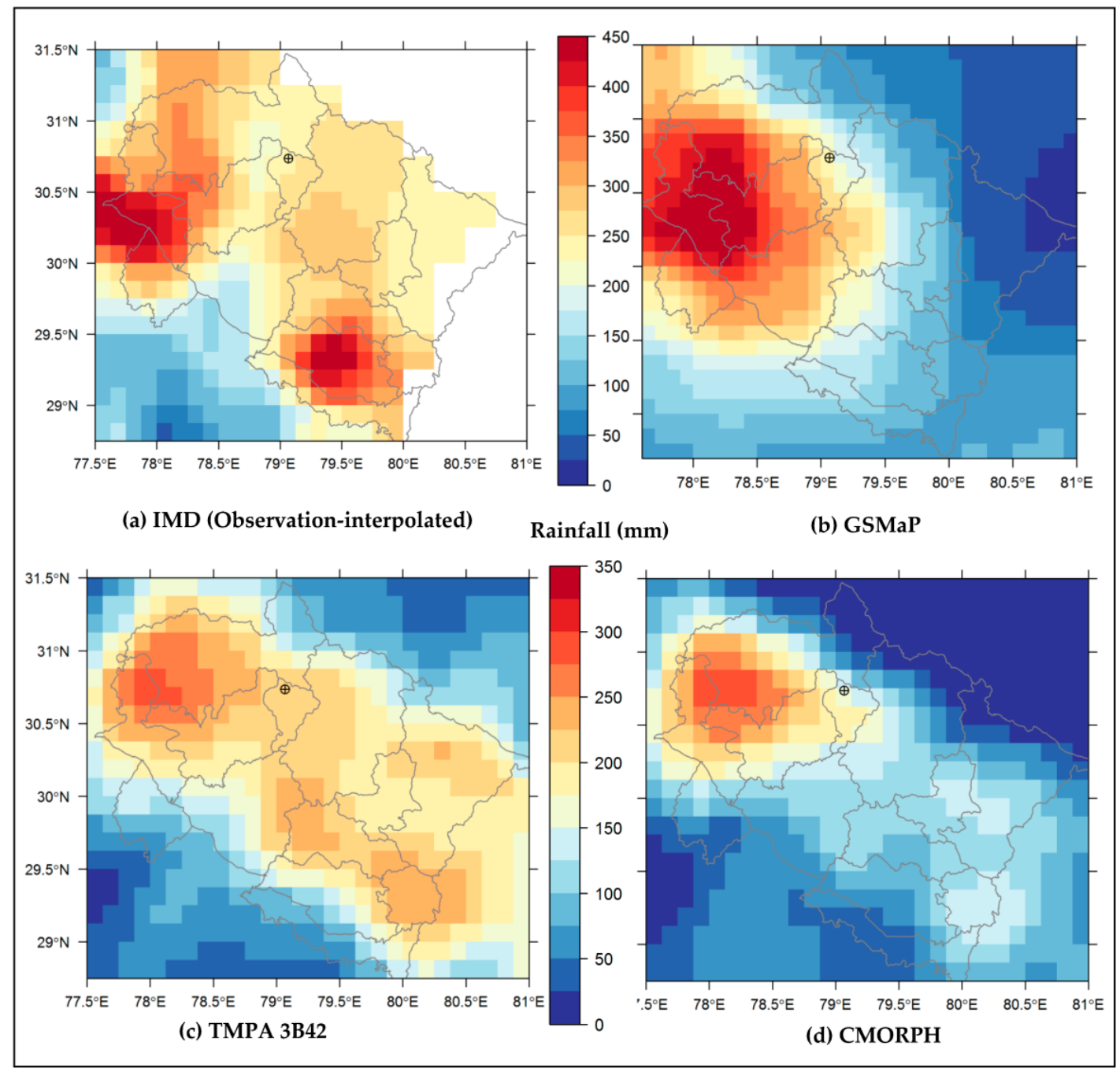

Figure 2. Spatial patterns of accumulated daily precipitation (mm): (a) IMD (observation-interpolated); (b) GSMaP; (c) TMPA 3B42; and (d) CMORPH during the peak storm during 15-18 June 2013 over Uttarakhand state. The circular plus symbol denotes location of Kedarnath.

\subsection{SBRE Rainfall Products Validation against IMD Using Statistical Metrics}

As shown in Figure 2, it was observed that precipitation pattern being well distributed, especially over all northern districts, namely, Uttrakashi, Rudraprayag, Thehri Garhwal, and Dehradun, across the three SBRE rainfall products (GSMaP, TMPA, and CMORPH). To compare three SBRE rainfall products over these districts with the benchmark data IMD, 82 random points were selected, and the distributions of these points have been shown in Figure 3a. The scatterplots of precipitation during peak storm over four days (15-18 June) with respect to IMD gauge-based data (Figure 3) exhibited overestimation of precipitation by GSMaP, while underestimation by TMPA and CMORPH irrespective of lower or higher surface elevations. In all three cases (Figure 3b-d), these comparisons were statistically significant at $p$ value $<0.001(d f=80)$ with Pearson's coefficient of determination $\left(R^{2}\right)$ in the range from 0.42 to 0.44 .

The quantitative error statistics are presented in Table 2, wherein PBIAS suggests an outcome of both positive (GSMaP) and negative (TMPA-3B42 and CMORPH) bias of satellite estimates. Both MAE and NRMSE showed that the errors increased from TMPA to CMORPH. The NRMSE values were $21.5 \%, 28 \%$, and 33\% for TMPA-3B42, GSMAP, and CMORPH, respectively. The TMPA-3B42 satellite estimates showed smaller NRMSE value than the others, suggesting a better performance over GSMaP 
and CMORPH. The NSE indicator showed that TMPA was more closure towards zero than the others. Among three satellite rainfall products used in this study, we confirm that TMPA-3B42 performed better than other two products for this single extreme event.

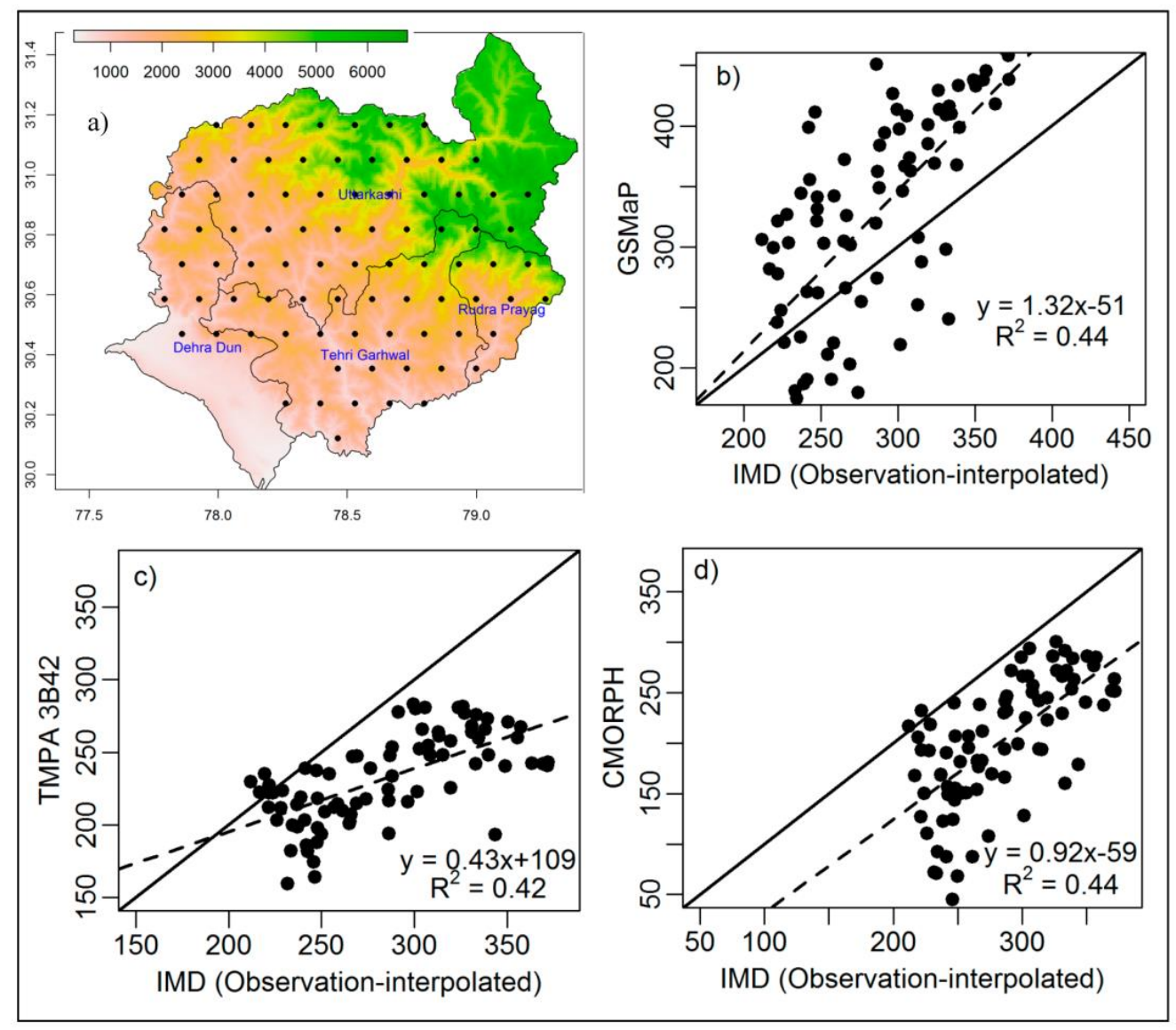

Figure 3. The distribution of 82 random points is shown in (a) along with surface elevation (m). Scatterplots depicted accumulated precipitation ( $\mathrm{mm}$ ) of IMD (observation-interpolated) vs. (b) GSMaP; (c) TMPA-3B42; and (d) CMORPH products. The accumulated precipitation data correspond to the peak storm during 15-18 June 2013. Solid lines represent the 1:1 line and dashed lines represent the least square regression line. Regression slope and $R^{2}$ values are also given in each plot.

Table 2. Results of statistical error parameters to compare satellite-based rainfall products with gauge data (IMD). The number of data pairs used was 82 .

\begin{tabular}{cccc}
\hline Parameters & TMPA-3B42 (v7) & GSMaP & CMORPH \\
\hline PBIAS (\%) & -18.2 & 14.4 & -29.0 \\
MAE (mm) & 52.7 & 71.8 & 82.5 \\
NRMSE (\%) & 21.5 & 28.0 & 33.0 \\
NSE & -0.93 & -2.25 & -3.52 \\
\hline
\end{tabular}

As Kedarnath (Rudraprayag district) was considered to be the most affected region in all aspects in that vicinity, we derived the mass curve and hyetograph specifically from TMPA-3B42 for this extreme rainfall event during 8-22 June across Kedarnath (Figure 4). The mass curve typically represents the accumulated precipitation over time. The plotted values represent the areal averaged across $78.5^{\circ}$ to $79.5^{\circ}$ longitude and $30.5^{\circ}$ to $31.5^{\circ}$ latitude encompassing Kedarnath and nearby regions. From this plot, we inferred that two distinct storms took place during this entire period, with the first storm detected during 9-11 June and the second one during 14-17 June. In the first phase of storm, this 
region received the accumulated precipitation of $131 \mathrm{~mm}$, whereas the second storm contributed the precipitation of $219 \mathrm{~mm}$. Thereafter, rainfall was reduced gradually, which can be visualized in the mass curve (Figure 4). The hyetograph depicts the rainfall intensity per day, and it suggests that heavy precipitation occurred during 10 and 11 June. The corresponding precipitation rates were observed as 45 and $75 \mathrm{~mm} /$ day, respectively. Furthermore, during the second storm, the estimated precipitation was $>50 \mathrm{~mm} /$ day, with a maximum of $105 \mathrm{~mm} /$ day on 16 June.

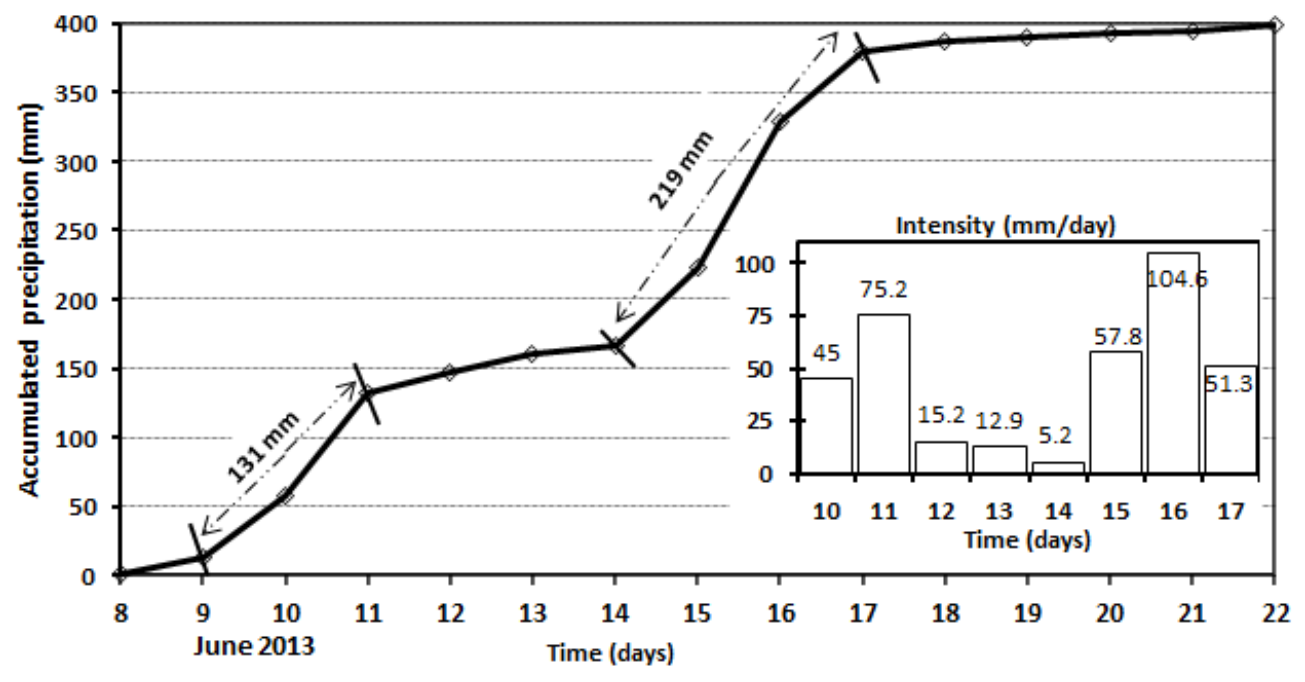

Figure 4. Mass curve of area averaged precipitation (TMPA-3B42 daily) during 8 to 22 June 2013 across $78.5^{\circ}$ to $79.5^{\circ} \mathrm{E}$ and $30.5^{\circ}$ to $31.5^{\circ} \mathrm{N}$ in Kedarnath and surrounding regions. The inset plot indicates hyetograph of a storm showing intensity of precipitation ( $\mathrm{mm} /$ day).

The worst affected districts due to this extreme rainfall event were Chamoli, Rudraprayag, Uttarkashi, and Pithoragarh. The rain gauge stations of IMD located over these districts recorded rainfall between 214 and $390 \mathrm{~mm}$ during 14-18 June 2013, with the maximum rainfall being recorded at Jakoli in Rudraprayag district (Table 3). As compared to IMD gauge point observations, TMPA-3B42 has estimated rainfall of $228 \mathrm{~mm}$ over Kedarnath, while WIHG Kopardhar observatory station near Ghuttu (Kedarnath) had recorded rainfall of $275 \mathrm{~mm}$. The estimated relative bias was computed as 17\% with respect to WIHG station. The maximum intensity of rainfall estimated by TMPA-3B42 was observed on 16 June ( $105 \mathrm{~mm} /$ day) over Kedarnath in Rudraprayag, whereas the ground-based observations exhibited 121 and $122 \mathrm{~mm}$ /day on 16 June at Jakoli and WIHG Kopardhar in Rudraprayag, respectively. These results suggested that the maximum intensity, including the peak storm date, was captured well by TMPA-3B42, however, the magnitude of the peak intensity rainfall was underestimated by $14 \%$ compared to rain gauge observations.

Table 3. Stationwise rainfall (mm) over Uttarakhand during 14-18 June 2013.

\begin{tabular}{cccc}
\hline Rain-Gauge Stations & $\begin{array}{c}\text { Accumulated } \\
\text { Rainfall }\end{array}$ & $\begin{array}{c}\text { Maximum Intensity } \\
\text { (mm/Day) }\end{array}$ & $\begin{array}{c}\text { Maximum Intensity } \\
\text { (Date) }\end{array}$ \\
\hline (IMD gauge-based point observations) \\
Uttarkashi & 359 & 162 & 17 June \\
Jakoli, Rudraprayag & 390 & 121 & 16 June \\
Tharali, Chamoli & 326 & 173 & 17 June \\
Pithoragarh & 214 & 117.2 & 18 June \\
\hline \multicolumn{5}{c}{ (WIHG observatory near Kedarnath) } \\
Kopardhar, Ghuttu & 275 & 122 & 16 June \\
\hline \multicolumn{5}{c}{ Kedarnath } & (TMPA-3B42 (area averaged over Kedarnath, Figure 4) \\
& 227.5 & 105 & 16 June \\
\hline
\end{tabular}




\subsection{Observed Discharge Rate at Sitapur (Gaurikund) during 1-16 June 2013}

The heavy precipitation, snowfall, or glacier melting usually cause high stages in river flow and, hence, the river discharge data should have correspondence with extreme rainfall events. The daily discharge rate observed at Sitapur (Gaurikund) in Mandakini valley in the first half of June (1 to 15 June) during 2008-2012 varied from 19 to $160 \mathrm{~m}^{3} / \mathrm{s}$. The mean discharge was estimated as $45 \mathrm{~m}^{3} / \mathrm{s}$ over 2008-2012 during the first half of June, whereas the mean discharge of the first half of June during 2013 was $75 \mathrm{~m}^{3}$ / s (Figure 5). The observed daily discharge data at Sitapur (Gaurikund) during June 2013 indicated a sudden rise in discharge, up to $1378.5 \mathrm{~m}^{3} / \mathrm{s}$ on 16 June, with the mean being $75 \mathrm{~m}^{3} / \mathrm{s}$. There was no significant rainfall prior to 9 June, but the discharge rate varied from 54 to $65 \mathrm{~m}^{3} / \mathrm{s}$ could be attributed to glacier and snowmelt runoff. After 9 June, the river discharge increased from 65 to $132 \mathrm{~m}^{3} / \mathrm{s}$ at Sitapur (Gaurikund). The peak discharge of $132 \mathrm{~m}^{3} / \mathrm{s}$ was recorded on 11 June, which was consistent with the maximum intensity of rainfall $(75 \mathrm{~mm} /$ day) during the first storm in Kedranath valley (Figure 4). During the second storm, the peak discharge was observed at Sitapur (Gaurikund) on 16 June, which was consistent with the maximum intensity of rainfall (105 mm/day) on 16 June. The discharge rate on 16 June was significantly high $\left(1378.5 \mathrm{~m}^{3} / \mathrm{s}\right)$, which was attributed to various reasons, but primarily due to the outburst of the moraine-dammed Chorabari Lake [3] associated with this extreme rainfall. These results showed that the corresponding higher discharge rate during June 2013 has a good correspondence with the maximum rainfall intensity.

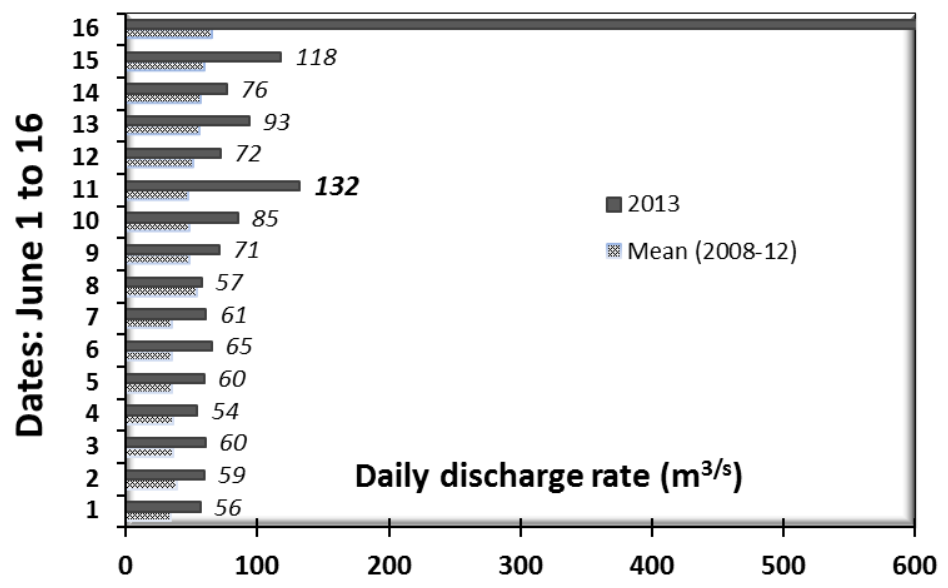

Figure 5. Daily discharge $\left(\mathrm{m}^{3} / \mathrm{s}\right)$ observed at Sitapur (Gaurikund) in Mandakini valley in June during 2013 against the daily mean over June 2008-2012.

\subsection{GIS-Based Mapping of Affected Villages and Population}

From the previous section, it should be noted that there were two consecutive storms between 9-11 June and 14-17 June 2013. Due to such extreme rainfall events, many studies have reported that the lake situated in Chorabari glacier above Kedarnath in Rudraprayag district burst, causing flash floods and debris flow [3,52]. This hydro-meteorological disaster caused heavy destruction and inundation of many villages in the state. It was reported that flash floods damaged more than 4200 villages, affecting almost 0.5 million people across 13 districts in Uttarakhand [53]. More than 600 villages were severely damaged (washed away/submerged) in four districts, namely, Chamoli (143 villages), Rudraprayag (134 villages), Uttarkashi (196 villages), and Pithoragarh (151 villages). In order to highlight some of the risk elements of the Kedranath disaster 2013, we performed GIS mapping of affected villages and populations along the Mandakini valley.

Figure 6 depicts the GIS map of some of the worst affected downstream villages of Rudraprayag district along with their population. According to Rudraprayag-Uttarakhand District Administration [42], out of 134 affected villages, 74 villages were isolated, affecting 25,000 people, and the remaining villages were highly affected. We mapped 27 highly-affected villages across Rudraprayag district, along with 
their population size, location, and surface elevation. These results show that the five worst-affected villages having a population of more than 1000 were located in Trijugi Narayan (1360 population), Ukhimath (2296), Raulek (1210), Kyunja (1028), Baniyari (1100), and these villages represent an affected population of nearly 7000. The affected villages with populations of 500 to 1000 were Barasu, Jalmalla, Kalimath, Kotma, Uniyara, Jaggi Bagwan, Guptkashi, Bhiri, Kamsal, Pillu, Rumsi, Satera, Bhatwari Sunar, and Jogoth. Under this category, the total affected population was observed to be 8660. The remaining affected villages were under a population size of 500, and among those villages, Kedarnath town had a residential population of 482.

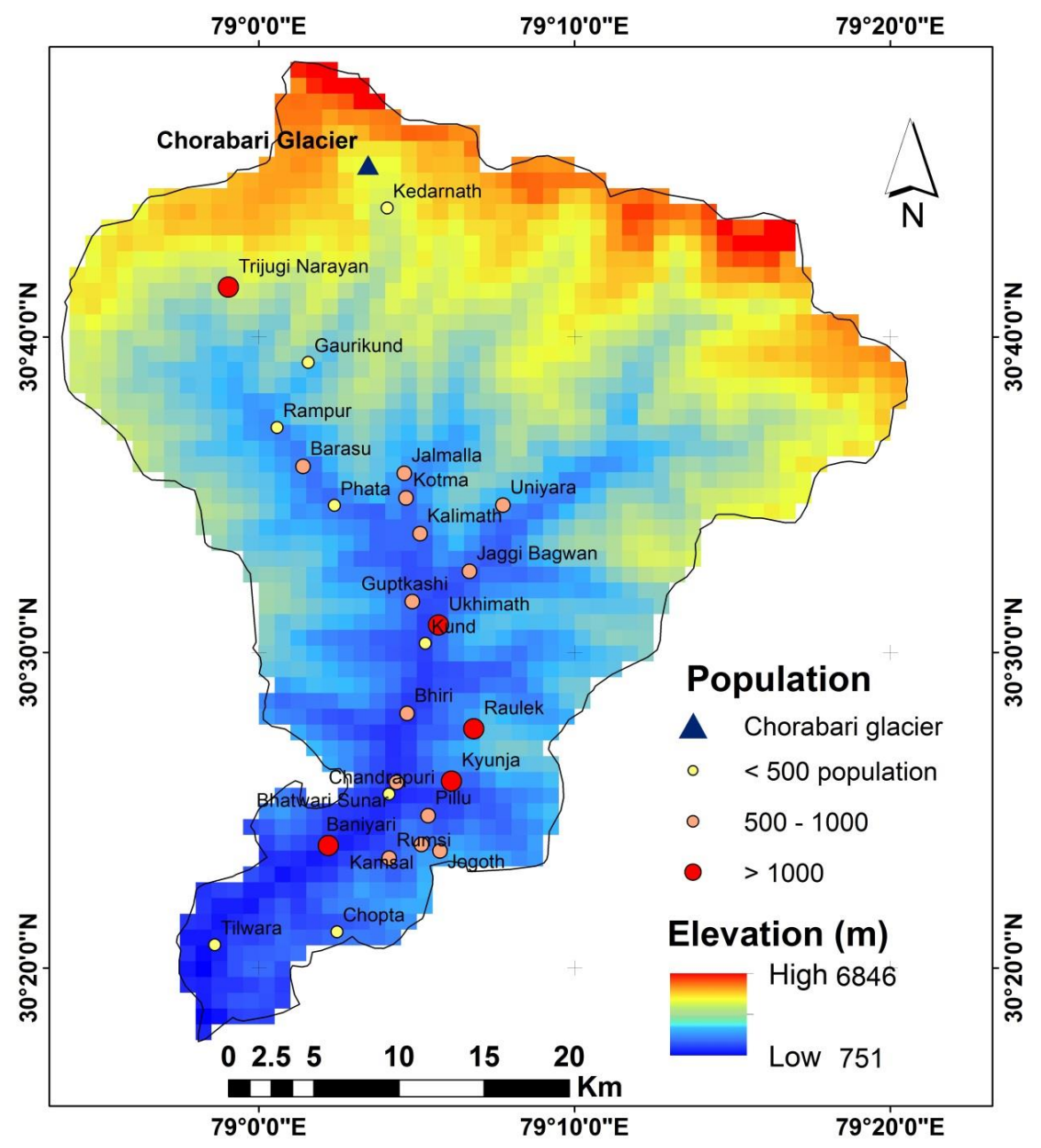

Figure 6. The worst-affected villages of Rudraprayag district along with the elevation. The varying size of circles indicates the affected population due to the June 2013 disaster.

From the topographic profile of the region (elevation in Figure 6), it has been clearly observed that Chorabari Lake (which eventually burst) was located at higher elevation, causing the excess flooded water to inundate the lower plain areas in the downstream region.

One of the important elements of risk is the "historical Kedarnath heritage", well-known for tourist and religious pilgrimage sites. This heritage and township (located just below the lake) were washed away fully due to flash floods triggered by this extreme rainfall event. The Kedarnath temple remained unaffected; however, the buildings around it were precariously damaged. In the aftermath of the disaster, more than 5000 fatalities were witnessed, and this natural disaster affected over 0.11 million of pilgrims and tourists [53]. Based on Uttarakhand Tourism Department [47] data, our analysis depicted that the number of Kedarnath pilgrims was 0.215 million in 2000 and had increased to 0.548 million 
in 2012 (Table 4). The numbers of pilgrims to Kedarnath and adjacent tourist spots (e.g., Badarinath) have dropped down considerably by $80 \%$ to $90 \%$ since the June 2013 disaster. It was estimated that the numbers of pilgrims visited were $\sim 0.312$ and 0.040 million in 2013 and 2014, respectively, which signified the serious effects of this natural disaster on tourism and revenue collection of this state of Uttrakhand.

Table 4. Number of pilgrims and tourists (in million) visited to Kedarnath and adjacent tourist spots (Badarinath) during 1990-2015.

\begin{tabular}{ccc}
\hline Years & Kedarnath & Badrinath \\
\hline 1990 & 0.117 & 0.362 \\
2000 & 0.215 & 0.735 \\
2005 & 0.390 & 0.566 \\
2010 & 0.400 & 0.921 \\
2012 & 0.548 & 0.986 \\
2013 & 0.312 & 0.497 \\
2014 & 0.048 & 0.180 \\
2015 & 0.154 & 0.359 \\
\hline
\end{tabular}

\section{Discussions and Conclusions}

The SBRE rainfall products at varying spatial and temporal resolutions are crucial for a broad variety of hydrological applications covering regional scale to global scale studies. In particular, it was useful in data-sparse regions, rugged terrain conditions, and regions with limited in situ observational setups $[54,55]$. Our overarching objective was to evaluate three SBRE products, such as TMPA-3B42, GSMaP, and CMORPH, against the observational dataset of IMD for an extreme unexpected event like the June 2013 Kedarnath disaster. The biases of SBRE rainfall products might lead to underestimation or overestimation of precipitation over a catchment area. Our findings suggested that the multi-phase extreme rainfall events resembled cloudburst type of event can be detected using the hourly or daily satellite-based rainfall products from TMPA-3B42, GSMaP, and CMORPH over these highly-heterogeneous topographical and inaccessible areas with lower rain-gauge networks. Based on these SBRE rainfall products, we found that heavy downpours of more than $200 \mathrm{~mm}$ occurred during 15-18 June, particularly over the northern districts of the state. Over the Kedranath region of Rudraprayag we detected that, prior to the second storm during 14-17 June (accumulated $219 \mathrm{~mm}$ ), heavy precipitation events were also observed during 9-11 June (first storm), and the accumulated precipitation was $131 \mathrm{~mm}$. The estimated accumulated precipitation from TMPA-3B42 was close to WIHG-based rain-gauge data, but lower than that of IMD observations (Table 3). Specifically over Kedarnath, the maximum intensity of rainfall and the corresponding maximum intensity dates obtained from TMPA-3B42 were consistent with the gauge-based data located at Jakoli (Rudraprayag) and Kopardhar (Rudraprayag). However, the magnitude of peak intensity rainfall was underestimated by $14 \%$ in comparison to IMD or WIHG observations.

The spatial distribution and amount of rainfall from TMPA-3B42, GSMaP, and CMORPH during June 2013 extreme rainfall event especially over northern districts of the state were comparable against the ground based rain-gauged IMD dataset, albeit the latter two were overestimated and underestimated, respectively. These rainfall comparisons exhibited that they were statistically significant ( $p$ value $<0.001$ ) with $R^{2}$ ranging from 0.42 to 0.44 . The accumulated precipitation estimated by CMORPH was underestimated considerably as this product was not gauge-calibrated. The error statistics such as PBIAS, MAE, NRMSE, and NSE for CMORPH were higher compared to both TMPA and GSMaP (Table 2). The gauge-calibrated products, such as GSMaP and TMPA have performed better against IMD gauge-based data especially over northern districts of the state. Based-on this major extreme event analysis, the error statistics indicator showed that TMPA-3B42 performed better against reference IMD data. The underestimation of TMPA-based rainfall over the Mandakini valley was also reported by Mishra and Srinivasan [56] and Bharti et al. [57]. The algorithms used for these 
satellite rainfall products lack regional factors and orographic settings for precipitation estimation and, apparently, the rainfall biases were observed over this highly complex Himalayan region. Typically underestimation of precipitation might be attributed to warm orographic rain that cannot be detected by IR and MW sensors. The IR retrievals use cloud-top temperature thresholds that are too cold for the orographic clouds, hence, leading to an underestimation of orographic rains [19]. The PMW retrievals over complex topography regions were typically attributed to warm orographic clouds without ice particles that produce heavy rain [58]. Nevertheless, these data were valuable input source for hydrological applications and modelling. Particularly, SBRE gauge-calibrated rainfall products were very useful compared to non-calibrated products for monitoring extreme rainfall events in real-time over a catchment area. The satellite rainfall estimates have both positive and negative biases irrespective of surface elevation and, therefore, these caveats must be considered for hydrological studies and applications.

During the period of the second storm, Mandakini basin was accompanied by a massive water flow due to the sudden outburst of the moraine-dammed Chorabari Lake (i.e., $2 \mathrm{~km}$ upstream from Kedarnath). A recent study by Durga Rao [52], which estimated that about 0.40 million $\mathrm{m}^{3}$ of water was accumulated prior to the outburst of the Lake indicated the possibility of the potential threat of a high velocity of water flow for the downstream areas. The volume of rainwater and water flow due to the collapse of the moraine-dammed Chorabari Lake caused havoc, especially in Kedarnath and along the Mandakini valley. Gupta et al. [24] reported that almost 0.10 million $\mathrm{m}^{3}$ of water released within $10 \mathrm{~min}$ of the lake outburst. The observed daily discharge data at Sitapur (Gaurikund) in Mandakini valley in June 2013 had indicated a sudden rise of discharge up to $1378.5 \mathrm{~m}^{3} / \mathrm{s}$ on 16 June, while the mean discharge of the first half of June month was $75 \mathrm{~m}^{3} / \mathrm{s}$ (Figure 5). Prior to 9 June, there was no significant rainfall, but a discharge rate varied from 54 to $65 \mathrm{~m}^{3} / \mathrm{s}$, suggestive of runoff from glacier and snowmelt. The satellite-based imageries indicated that, in winter 2013, there was increase in snowfall of $30 \%$ in the Alaknanda and Mandakini catchment area [59,60]. Previous studies reported that the extreme rainfall in June has caused an acceleration of snowmelt-runoff and accumulation of large volume of water in the Lake [52,61]. This, in turn, might have caused the higher discharge rate at Sitapur station (Gaurikund) during the second storm, where the river discharge was recorded from 65 to $132 \mathrm{~m}^{3} / \mathrm{s}$. This observation was consistent with Central Water Commission (CWC) data that reported a discharge of $150 \mathrm{~m}^{3} / \mathrm{s}$ in the Mandakini River due to snowmelt runoff prior to 16 June [52]. The discharge rate from the river could be linked with the intensity of rainfall from satellite estimates. We confirmed that the multi-storms extreme rainfall events had a good correspondence with the observed discharge rate over the Mandakini basin, albeit the runoff could be largely influenced by snowmelt processes [62]. During the post-lake outburst, the water flow velocity was so high that it washed away riverbanks and settlement areas and, thereby, it produced a very large amount of debris in the downstream region. The widespread landslides observed over Mandakini valley were triggered by heavy rainfall and flash floods of which the majority were activated due to riverbank erosion $[8,63]$. This caused significnat damage to the connectivity of major roads across the state, as well as the trekking way to Kedarnath temple.

In view of the prevalent affected villages and population, the number of fatalities, and the damage to property and infrastructure, the June 2013 event was considered as a major natural disaster in the history of this state, and the nation as well. This hydro-meteorological disaster might have an implicit correspondence with global climate change as some studies have confirmed the rate of glacier retreat increased significantly in the recent decade over the Chorabari glacier [25]. Rapid melting of snow has further led to the formation and expansion of moraine-dammed lakes and notably any damage of such dammed glacier lakes in the surrounding steep slope of hilly regions could repeat the GLOFs like the June 2013 extreme rainfall event in the future. Apparently, unplanned urbanization and infrastructure development might have increased the vulnerability of this region, including tourism regulations, which were not being implemented properly with respect to the current administrative procedures [64]. 
From the assessment through this comprehensive study, we inferred that information from satellite-based rainfall estimates provides first-hand reliable information on rainfall duration and intensity, flash floods, and related disaster intensities. Hence, based on the inputs from satellite information, mitigation measures and relief operations can be facilitated by the concerned public authorities to minimize the damage to human life, natural ecosystems, and anthropogenic setups in a region, where the sparsity of rainfall stations and inaccessible problems exist.

Acknowledgments: Our sincere thanks to NASA GES/DISC, JAXA, and CPC NOAA for providing satellite-based rainfall products. Thanks to IMD and WIHG for providing gridded daily rainfall and daily discharge data, respectively.

Author Contributions: B.R. Parida, S.N. Behera, and B. Oinam designed research and wrote the manuscript. A.C. Pandey and N. Singh contributed for editing the manuscript and gave constructive comments and suggestions.

Conflicts of Interest: The authors declare no conflict of interest.

\section{Acronyms}

$\begin{array}{ll}\text { SBRE } & \text { Satellite Based Rainfall Estimates } \\ \text { TRMM } & \text { Tropical Rainfall Measuring Mission } \\ \text { TMPA } & \text { TRMM Multisatellite Precipitation Analysis } \\ \text { GSMaP } & \text { Global Satellite Mapping of Precipitation } \\ \text { CMORPH } & \text { Climate Prediction Center Morphing method } \\ \text { GCPC-1DD } & \text { Global Precipitation Climatology Project One Degree Daily estimate } \\ \text { APHRODITE } & \text { Asian Precipitation-Highly-Resolved Observational Data Integration towards } \\ \text { RFE2 } & \text { Evaluation of Water Resources } \\ \text { IMD } & \text { African Rainfall Estimate } \\ \text { NCC } & \text { India Meteorological Department } \\ \text { NDC } & \text { National Climate Centre } \\ \text { WIHG } & \text { National Data Center } \\ \text { PMW } & \text { Wadia Institute of Himalayan Geology } \\ \text { NOAA } & \text { Passive Microwave Radiometer } \\ \text { CPC } & \text { National Oceanic and Atmospheric Administration } \\ \text { MAE } & \text { Climate Prediction Center } \\ \text { NRMSE } & \text { Mean Absolute Error } \\ \text { PBIAS } & \text { Normalized root mean square error } \\ \text { NSE } & \text { Percent Bias } \\ & \text { Nash-Sutcliffe efficiency }\end{array}$

\section{References}

1. Kotal, S.D.; Roy, S.S.; Bhowmik, S.K.R. Catastrophic heavy rainfall episode over Uttarakhand during 16-18 June 2013-Observational aspects. Curr. Sci. 2014, 107, 234-245.

2. Das, S.; Ashrit, R.; Moncrieff, M.W. Simulation of a Himalayan cloudburst event. J. Earth Syst. Sci. 2006, 115, 299-313. [CrossRef]

3. Rautela, P. Lessons learnt from the Deluge of Kedarnath, Uttarakhand, India. Asian J. Environ. Disaster Manag. 2013, 5, 43-51. [CrossRef]

4. Dani, S.; Motwani, A. India-Uttarakand Disaster: Joint Rapid Damage and Needs Assessment Report 2013; World Bank: Washington, DC, USA, 2013.

5. ICIMOD. Glacial Lakes and Glacial Lake Outburst Floods in Nepal; International Centre for Integrated Mountain Development (ICIMOD): Kathmandu, Nepal, 2011.

6. Bookhagen, B.; Burbank, D.W. Toward a complete Himalayan hydrological budget: Spatiotemporal distribution of snowmelt and rainfall and their impact on river discharge. J. Geophys. Res. 2010, 115. [CrossRef]

7. Bharti, V.; Singh, C. Evaluation of error in TRMM 3B42V7 precipitation estimates over the Himalayan region: EVALUATION OF ERROR IN TRMM 3B42V. J. Geophys. Res. Atmos. 2015, 120, 12458-12473. [CrossRef] 
8. Prakash, S.; Mitra, A.K.; Rajagopal, E.N.; Pai, D.S. Assessment of TRMM-based TMPA-3B42 and GSMaP precipitation products over India for the peak southwest monsoon season: ASSESSMENT OF TMPA AND GSMAP PRECIPITATION PRODUCTS OVER INDIA. Int. J. Climatol. 2016, 36, 1614-1631. [CrossRef]

9. Chandra, M.; Kumar, R.; Kannan, B.A.M.; Reddy, Y.K.; Sastry, P.S. Standard Operating Procedure for Doppler Weather Radar-98d/s; Weather Radar Division, India Meteorol. Dep. Minist. Earth Sci., Gov. India: New Delhi, India, 2011.

10. Huffman, G.J. Estimates of Root-Mean-Square Random Error for Finite Samples of Estimated Precipitation. J. Appl. Meteorol. 1997, 36, 1191-1201. [CrossRef]

11. Huffman, G.J.; Bolvin, D.T.; Nelkin, E.J.; Wolff, D.B.; Adler, R.F.; Gu, G.; Hong, Y.; Bowman, K.P.; Stocker, E.F. The TRMM Multisatellite Precipitation Analysis (TMPA): Quasi-Global, Multiyear, Combined-Sensor Precipitation Estimates at Fine Scales. J. Hydrometeorol. 2007, 8, 38-55. [CrossRef]

12. Gosset, M.; Viarre, J.; Quantin, G.; Alcoba, M. Evaluation of several rainfall products used for hydrological applications over West Africa using two high-resolution gauge networks. Q. J. R. Meteorol. Soc. 2013, 139, 923-940. [CrossRef]

13. Hamada, A.; Murayama, Y.; Takayabu, Y.N. Regional Characteristics of Extreme Rainfall Extracted from TRMM PR Measurements. J. Clim. 2014, 27, 8151-8169. [CrossRef]

14. Zhao, H.; Yang, S.; Wang, Z.; Zhou, X.; Luo, Y.; Wu, L. Evaluating the suitability of TRMM satellite rainfall data for hydrological simulation using a distributed hydrological model in the Weihe River catchment in China. J. Geogr. Sci. 2015, 25, 177-195. [CrossRef]

15. Parida, B.R.; Collado, W.B.; Borah, R.; Hazarika, M.K.; Samarakoon, L. Detecting Drought-Prone Areas of Rice Agriculture Using a MODIS-Derived Soil Moisture Index. GIScience Remote Sens. 2008, 45, 109-129. [CrossRef]

16. Li, Z.; Yang, D.; Hong, Y. Multi-scale evaluation of high-resolution multi-sensor blended global precipitation products over the Yangtze River. J. Hydrol. 2013, 500, 157-169. [CrossRef]

17. Li, Z.; Yang, D.; Gao, B.; Jiao, Y.; Hong, Y.; Xu, T. Multiscale Hydrologic Applications of the Latest Satellite Precipitation Products in the Yangtze River Basin using a Distributed Hydrologic Model. J. Hydrometeorol. 2015, 16, 407-426. [CrossRef]

18. Krajewski, W. Ground networks: Are we doing the right things? In Measuring Precipitation from Space-EURAINSAT and the Future; Levizzani, V., Bauer, P., Turk, F.., Eds.; Springer: Dordrecht, The Netherlands, 2007; Volume 28, pp. 403-417.

19. Dinku, T.; Chidzambwa, S.; Ceccato, P.; Connor, S.J.; Ropelewski, C.F. Validation of high-resolution satellite rainfall products over complex terrain. Int. J. Remote Sens. 2008, 29, 4097-4110. [CrossRef]

20. Gebregiorgis, A.S.; Hossain, F. How well can we estimate error variance of satellite precipitation data around the world? Atmos. Res. 2015, 154, 39-59. [CrossRef]

21. Artan, G.; Gadain, H.; Smith, J.L.; Asante, K.; Bandaragoda, C.J.; Verdin, J.P. Adequacy of satellite derived rainfall data for stream flow modeling. Nat. Hazards 2007, 43, 167-185. [CrossRef]

22. Bookhagen, B.; Burbank, D.W. Topography, relief, and TRMM-derived rainfall variations along the Himalaya. Geophys. Res. Lett. 2006, 33. [CrossRef]

23. McCollum, J.R.; Gruber, A.; Ba, M.B. Discrepancy between Gauges and Satellite Estimates of Rainfall in Equatorial Africa. J. Appl. Meteorol. 2000, 39, 666-679. [CrossRef]

24. Gupta, A.K.; Dobhal, D.P.; Mehta, M.; Verma, A.; Pratap, B.; Kesarwani, K. A Report on Kedarnath Devastation; Wadia Institute of Himalayan Geology: Dehradun, Uttrakhand, India, 2013; pp. 1-64.

25. Mehta, M.; Dobhal, D.P.; Kesarwani, K.; Pratap, B.; Kumar, A.; Verma, A. Monitoring of Glacier Changes and Response Time in Chorabari Glacier, Central Himalaya, Garhwal, India. Curr. Sci. 2014, 107, 281-289.

26. DMMC Report. Geological Investigations in Rudraprayag District with Special Reference to Mass Instability; Disaster Mitigation and Management Centre, Gov. of Uttarakhand: Uttarakhand, India, 2014.

27. Huffman, G.J.; Adler, R.F.; Bolvin, D.T.; Nelkin, E.J. The TRMM Multi-Satellite Precipitation Analysis (TMPA). In Satellite Rainfall Applications for Surface Hydrology; Gebremichael, M., Hossain, F., Eds.; Springer: Dordrecht, The Netherlands, 2010; pp. 3-22.

28. Huffman, G.J.; Bolvin, D.T. TRMM and Other Data Precipitation Data Set Documentation 2013. Available online: ftp:/ / meso-a.gsfc.nasa.gov/pub/trmmdocs/3B42_3B43_doc.pdf (accessed on 5 July 2016). 
29. Shepard, D. A Two-dimensional Interpolation Function for Irregularly-spaced Data. In Proceedings of the 1968 23rd ACM National Conference, Las Vegas, NV, USA, 27-29 August 1968; ACM: New York, NY, USA, 1968; pp. 517-524.

30. Pai, D.S.; Sridhar, L.; Rajeevan, M.; Sreejith, O.P.; Satbhai, N.S.; Mukhopadhyay, B. Development of a new high spatial resolution $\left(0.25^{\circ} \times 0.25^{\circ}\right)$ long period (1901-2010) daily gridded rainfall data set over India and its comparison with existing data sets over the region. Mausam 2014, 65, 1-18.

31. Joyce, R.J.; Janowiak, J.E.; Arkin, P.A.; Xie, P. CMORPH: A Method that Produces Global Precipitation Estimates from Passive Microwave and Infrared Data at High Spatial and Temporal Resolution. J. Hydrometeorol. 2004, 5, 487-503. [CrossRef]

32. Ushio, T.; Sasashige, K.; Kubota, T.; Shige, S.; Okamoto, K.; Aonashi, K.; Inoue, T.; Takahashi, N.; Iguchi, T.; Kachi, M.; et al. A Kalman Filter Approach to the Global Satellite Mapping of Precipitation (GSMaP) from Combined Passive Microwave and Infrared Radiometric Data. J. Meteorol. Soc. Jpn. Ser II 2009, 87A, 137-151. [CrossRef]

33. Janowiak, J.E.; Kousky, V.E.; Joyce, R.J. Diurnal cycle of precipitation determined from the CMORPH high spatial and temporal resolution global precipitation analyses. J. Geophys. Res. 2005, 110. [CrossRef]

34. Ushio, T.; Tashima, T.; Kubota, T.; Kachi, M. Gauge Adjusted Global Satellite Mapping of Precipitation (GSMaP_Gauge). In Proceedings of the 29th ISTS, Nagoya, Japan, 2-9 June 2013.

35. Pai, D.S.; Sridhar, L.; Badwaik, M.R.; Rajeevan, M. Analysis of the daily rainfall events over India using a new long period (1901-2010) high resolution $\left(0.25^{\circ} \times 0.25^{\circ}\right)$ gridded rainfall data set. Clim. Dyn. 2015, 45, 755-776. [CrossRef]

36. Rajeevan, M.; Bhate, J. A high resolution daily gridded rainfall dataset (1971-2005) for mesoscale meteorological studies. Curr. Sci. 2009, 96, 558-562.

37. Krishnamurthy, V.; Shukla, J. Intraseasonal and Seasonally Persisting Patterns of Indian Monsoon Rainfall. J. Clim. 2007, 20, 3-20. [CrossRef]

38. Krishnamurthy, V.; Shukla, J. Seasonal persistence and propagation of intraseasonal patterns over the Indian monsoon region. Clim. Dyn. 2008, 30, 353-369. [CrossRef]

39. Srinivasan, J.; Joshi, P.C. What have we learned about the Indian monsoon from satellite data? Curr. Sci. 2007, 93, 165-172.

40. Yatagai, A.; Kamiguchi, K.; Arakawa, O.; Hamada, A.; Yasutomi, N.; Kitoh, A. APHRODITE: Constructing a Long-Term Daily Gridded Precipitation Dataset for Asia Based on a Dense Network of Rain Gauges. Bull. Am. Meteorol. Soc. 2012, 93, 1401-1415. [CrossRef]

41. Dobhal, D.P.; Gupta, A.K.; Mehta, M.; Khandelwal, D.D. Kedarnath disaster: Facts and plausible causes. Curr. Sci. 2013, 105, 171-174.

42. Rudraprayag-Uttarakhand District Administration 2014. Available online: http://rudraprayag.nic.in (accessed on 5 August 2016).

43. Census India. 2011. Available online: http:/ / census2011.co.in (accessed on 5 June 2016).

44. Devastating Flash Floods in Uttarakhand and Himachal Pradesh 2013, Pragya. Available online: www. pragya.org/doc/flashflood_update.pdf (accessed on 5 February 2015).

45. Report for Relief Work Uttarakhand Disaster 2013 by Partners of Association for India's Development, AID-JHU. Available online: www.aidjhu.org (accessed on 5 May 2016).

46. Global 30 Arc-Second Elevation (GTOPO30) I The Long Term Archive. Available online: https://lta.cr.usgs. gov/GTOPO30 (accessed on 8 May 2016).

47. Uttarakhand Tourism Development Board (UTDB). Available online: http://uttarakhandtourism.gov.in (accessed on 20 October 2016).

48. Hijmans, R.J.; van Etten, J.; Cheng, J.; Mattiuzzi, M.; Sumner, M.; Greenberg, J.A.; Lamigueiro, O.P.; Bevan, A.; Racine, E.B.; Shortridge, A.; et al. Geographic Data Analysis and Modeling [R package Raster Version 2.5-2]. Available online: https:/ /CRAN.R-project.org/package=raster (accessed on 15 February 2016).

49. Pebesma, E.; Bivand, R.; Rowlingson, B.; Gomez-Rubio, V.; Hijmans, R.; Sumner, M.; MacQueen, D.; Lemon, J.; O’Brien, J. Classes and Methods for Spatial Data [R package sp version 1.2-1]. Available online: https: / /CRAN.R-project.org/package=sp (accessed on 5 March 2016).

50. Nash, J.E.; Sutcliffe, J.V. River flow forecasting through conceptual models part I-A discussion of principles. J. Hydrol. 1970, 10, 282-290. [CrossRef] 
51. Legates, D.R.; McCabe, G.J. Evaluating the use of "goodness-of-fit" Measures in hydrologic and hydroclimatic model validation. Water Resour. Res. 1999, 35, 233-241. [CrossRef]

52. Durga Rao, K.H.V.; Rao, V.V.; Dadhwal, V.K.; Diwakar, P.G. Kedarnath flash floods: A hydrological and hydraulic simulation study. Curr. Sci. 2014, 106, 598-603.

53. Chopra, R. Uttarakhand: Development and Ecological Sustainability; Oxfam: New Delhi, India, 2014.

54. Hong, Y.; Adler, R.F.; Negri, A.; Huffman, G.J. Flood and landslide applications of near real-time satellite rainfall products. Nat. Hazards 2007, 43, 285-294. [CrossRef]

55. Shrestha, M.S.; Artan, G.A.; Bajracharya, S.R.; Sharma, R.R. Using satellite-based rainfall estimates for streamflow modelling: Bagmati Basin: Rainfall estimates for streamflow modelling. J. Flood Risk Manag. 2008, 1, 89-99. [CrossRef]

56. Mishra, A.; Srinivasan, J. Did a cloud burst occur in Kedarnath during 16 and 17 June 2013? Curr. Sci. 2013, 105, 1351-1352.

57. Bharti, V.; Singh, C.; Ettema, J.; Turkington, T.A.R. Spatiotemporal characteristics of extreme rainfall events over the Northwest Himalaya using satellite data: SPATIOTEMPORAL CHARACTERISTICS OF EXTREME RAINFALL EVENTS. Int. J. Climatol. 2016, 36, 3949-3962. [CrossRef]

58. Dinku, T.; Connor, S.J.; Ceccato, P. Comparison of CMORPH and TRMM-3B42 over Mountainous Regions of Africa and South America. In Satellite Rainfall Applications for Surface Hydrology; Gebremichael, M., Hossain, F., Eds.; Springer: Dordrecht, The Netherlands, 2010; pp. 193-204.

59. NRSC and Bhuvan. Available online: http://bhuvan.nrsc.gov.in/updates/gallery (accessed on 18 February 2016).

60. Allen, S.K.; Rastner, P.; Arora, M.; Huggel, C.; Stoffel, M. Lake outburst and debris flow disaster at Kedarnath, June 2013: Hydrometeorological triggering and topographic predisposition. Landslides 2016, 13, 1479-1491. [CrossRef]

61. Singh, D.; Horton, D.; Tsiang, M.; Haugen, M.; Ashfaq, M.; Mei, R.; Rastogi, D.; Johnson, N.; Charland, A.; Rajaratnam, B.; et al. Severe precipitation in northern India in June 2013: Causes, historical context, and changes in probability. Bull. Am. Meteorol. Soc. 2014, 95, S58-S61.

62. Siderius, C.; Biemans, H.; Wiltshire, A.; Rao, S.; Franssen, W.H.P.; Kumar, P.; Gosain, A.K.; van Vliet, M.T.H.; Collins, D.N. Snowmelt contributions to discharge of the Ganges. Sci. Total Environ. 2013, 468-469, S93-S101. [CrossRef] [PubMed]

63. NIDM, Uttarakhand. National Disaster Risk Reduction Portal; Ministry of Home Affairs, Gov. of India: New Delhi, India, 2014; pp. 1-20.

64. Semwal, R.; Kumar, K.; Dhyani, P.P. Regulating tourism and pilgrimage in the Himalaya. Curr. Sci. 2014, $106,797$.

(C) 2017 by the authors. Licensee MDPI, Basel, Switzerland. This article is an open access article distributed under the terms and conditions of the Creative Commons Attribution (CC BY) license (http:/ / creativecommons.org/licenses/by/4.0/). 